\title{
Impact of Shelter Forest Construction on Ecological and Economic Benefits in Horqin Region--Taking Horqin Left Wing Middle Banner As an Example
}

\author{
Changbao Yang ${ }^{1}$, Xiuqing $\mathrm{Wu}^{2}$ \\ ${ }^{1}$ School of Ethnology and Sociology, Inner Mongolia University, Huhhot, Inner Mongolia, 010021, China \\ ${ }^{2}$ Department of Environmental Engineering, Huhhot University for Nationalities, Hohhot, Inner Mongolia, \\ 010051, China
}

Keywords: Horqin Left Wing Middle Banner, Shelterbelt construction, Ecological and economic benefits.

\begin{abstract}
Vigorously building shelterbelts is an inevitable demand for improving ecological and economic benefits and realizing sustainable development. Combining with the special natural environment of Horqin Left Wing Middle Banner and the status quo of development of shelterbelt, it is necessary to take effective measures to expand the area of shelterbelt for sustainable development of ecology and economy in the Horqin area by adopting measures of planting, planting, combining grass, irrigation and grass according to local conditions and reasonable layout.
\end{abstract}

\section{Introduction}

Inner Mongolia has poor natural environment and less rainfall, with mountainous and sandy areas accounting for two-thirds of the total land area in Inner Mongolia. The Horqin Left Wing Middle Banner is both a grain production base in Inner Mongolia and an impoverished area with fragile ecological environment. In order to make ecological and economic sustainable development, Inner Mongolia Autonomous Region attaches great importance to the construction of shelterbelt in Horqin Left Wing Middle Banner. In 1981, it proposed the construction guideline of "shelterbelt-based, combination of tree and irrigation". However, due to various objective factors Influence and slow progress. Before 1992, the area of shrubs under construction in Inner Mongolia was less than one-third of the area built by shelterbelts. With the deepening of the strategy of developing the west, we should energetically develop the shelterbelt to control the land desertification and the industrial restructuring of agriculture and animal husbandry in Horqin Left Wing Middle Banner, improve the economic benefits of farmers and herdsmen, improve the ecological environment of Horqin Left Wing Middle Banner, and achieve long-term development The role of more and more prominent.

\section{The natural conditions in Horqin Left Wing Middle Banner}

Horqin Left Wing Middle Banner is located between 121 ${ }^{\circ} 09^{\prime} 48$ " $123^{\circ}$ 31'54" east longitude and $43^{\circ} 32^{\prime} 40$ " 44 ${ }^{\circ} 30^{\prime} 31^{\prime \prime}$ north latitude, bordering Jilin Province to the east and 4 to Tongliao City to the south Flag County connected north Hinggan League. Horqin Left Wing Middle Banner covers a total area of about 9811 square kilometers, the banner a total of 12 towns, 11 hematoxylin, 5 townships. Due to the geographical location and natural environment of Horqin Left Wing Middle Banner, there are 9 forest farms, 1 forest research institute and 2 nurseries classified according to the requirements of forestry management. These plots are reasonably distributed in towns and villages of the whole county wood.

The Horqin area is located in a temperate continental monsoon climate zone with less rainfall in spring and autumn, large sandstorms, rapid temperature changes, hot summers in summer, long winters, and cold and dry conditions. The average annual rainfall in Horqin Left Wing Middle Banner is only $370 \mathrm{~mm}$. Horqin Left Wing Middle Banner is generally low-lying, broad and evenly distributed, with an altitude of 120 to 230 meters. It is an important part of the Horqin area. Due to long-term river cutting and wind-blown accumulation, there are dunes in Horqin Left Wing Middle Banner, Manma and plains three types, and the three types of landscape gradually formed from the 
west to the east of three ridge-shaped sand belt, the terrain toward the northwest to southeast decreases, the unique topography also makes Horqin Left Wing Middle Banner vegetation and soil The type of zonal structure is simple. Horqin's unique topography and geomorphology make the process of soil erosion slow down, but the wind erosion rate is accelerating. Semi-dry climate makes the vegetation less, the existing types of vegetation only Mesozoic and xerophytic herb community. Sandy soil has a wide area of soil, meadow soil is mainly distributed in the lower reaches of Xinkaihe and Xiliaohe rivers, and the chestnut soil is mainly distributed in the eastern and northern areas of Horqin Left Wing Middle Banner.

\section{Status of Shelterbelt Construction in Horqin Left Wing Middle Banner}

Horqin Left Wing Middle Banner has been continuously implementing ecological construction and has successively completed the construction of the "Three-North" shelter forest project Phase III and the "5280" excellent model project, effectively carrying out the work of demarcation and division of forest classified management zones. Under the guidance of the "Three Norths" shelterbelt project construction, the project of returning farmland to forests, returning land for farming and animal husbandry and the Shuang Baisha Control Project, Branch Zuozhongqi successfully completed the construction of the second forest resources protection in 2002. The second investigation carried out the investigation on the status quo of all kinds of land resources construction in Horqin area, which provided accurate data support for the development of forestry long-term development plan of Horqin Left Wing Middle Banner.

Horqin Left Wing Middle Banner has a total land area of 981,100 hectares. So far, the area of forestry land is about 425,762 hectares, of which the forest area accounts for about 103,928 hectares, the shrub forest area 5643 hectares, the sparse forest area about 7024 hectares and the nursery area about 479 Hectare, man-made shrub forest area of about 4447 hectares, natural shrub forest area of about 1199 hectares, wasteland area of about 292575 hectares. These are non-commercial forests, the vegetation in the forest to Caragana, apricot-based, the total area planted $89 \%$ of the entire shelter forest, Caragana mainly distributed in Bayantala Town, Heber Flower Town, Zhu Rihe Town, Flowers Tuogula town, and Elan Sok town, apricot cultivation mainly in obo hematoxylin, Daiwa Kyrgyzstan and Haji dry figure hematoxylin. Strange Willow planting areas in Baixing, Haili cotton hemp, planted area accounts for about $6 \%$ of the total area of shelterbelts, planted alfalfa, seabuckthorn and other vegetation less, only distributed in Bayan called sumu, drawing Tuola Town and other regions.

Horqin Left Wing Middle Banner suitable for planting a total area of 292575 hectares of vegetation, and suitable for planting is fixed. There are 13,634 hectares of forest land not yet formed, and about 2,437 hectares of land has been returned to forestry. Horqin Left Wing Middle Banner can be said that suitable for planting vegetation and woodland is very rich in resources for Horqin Left Wing Middle Banner vigorously build shelterbelts, to protect and beautify the local environment has created a strong condition.

\section{The Significance of Building Protective Forest in Horqin Left Wing Middle Banner}

\subsection{Significance of environmental protection in desertification control}

Horqin Left Wing Middle Banner Sandy area, and the local climate is continental temperate monsoon climate, and in arid and semi-arid climate zone, the ecological environment is very fragile, it is easy to be destroyed, and once destroyed it is difficult restore.

Horqin Left Wing Middle Banner is located in the Horqin sandy land cover, the three monopoly big sand belt seriously hindered the development of the local economy, with the vigorous building of the windbreak and sand fixation project effectively curbed the process of desertification. However, due to the improper use of land resources such as reclamation of abandoned farmland and improper planting and production, land desertification is caused at a rate exceeding the speed of shelterbelt construction. Therefore, Horqin Left Wing Middle Banner attaches great importance to the 
construction of sand control and desertification projects, vigorously follow the guidance of returning farmland to forest, grassland, grazing and grazing projects, and continuously committed to afforestation and grass planting. And other channels, the combination of various forms of governance measures have greatly expanded the local forest coverage, and gradually realize the transformation of social and environmental benefits.

Horqin Left Wing Middle Banner actively respond to the State Forestry Administration and Inner Mongolia Forestry Department of ecological protection calls, has been committed to the construction of shelterbelts, and according to the characteristics of the local climate and land features to vigorously build shrubs, shrub resources in the protection of shrubs on the basis of continuous expansion Shrubland acreage, through the planting of shrubbery to prevent desertification, improve the deteriorating local ecological environment, improve the local economic development.

\subsection{Significance of shelterbelt construction in improving local ecological and economic benefits}

Horqin Left Wing Middle Banner geographical and natural environment determines the form of local forestry construction. Under the guidance of the ecological protection measures issued by the State Forestry Administration and the Inner Mongolia Forestry Department, Branch Zuozhongqi developed a planting form mainly consisting of shrubs and trees, combined with the local ecological environment.

Shrubs are highly adaptable and can grow in the sand. There are almond trees, Chinese wolfberry, Salix, strange willow, lilac, seabuckthorn and other vegetation, these plants have a common - drought, cold, wind erosion, salt, barren, resistant to stubble. Arbor fixation, soil conservation, beautification of the environment, climate regulation, the role of water conservation is very significant for the arid desert zone wind and sand, improve the role of the environment is hard to replace.

Horqin Left Wing Middle Banner is located in the arid and semi-arid zone with poor natural conditions and to a certain extent, the growth of trees can be inhibited. However, the shrubs are drought-tolerant and water-saving with strong vitality and reproductive capacity, stable growth and good sand fixation and prevention Wind erosion, water erosion, improve the ecological environment, control of farmland desertification, mixed planting of trees and shrubs can improve the resistance of pests and diseases pests rodents, and more stable play a role in maintaining the ecological health of the forest balance. Practice has proved that the protection and construction of shrubbery play an irreplaceable role in maintaining the balance of the Horqin ecosystem.

Many shrubs are not only good industrial raw materials, feedstuffs but also fuel and fertilizer. Such shrubs are vigorously planted to adjust the agricultural structure of Horqin Left Wing Middle Banner, improve local economic benefits and increase the per capita income of farmers and herdsmen. Shrubs can be used for wood-based panel production, industrial pulp and paper for industrial raw materials, but also can raise livestock; shrubs firm and soft branches, you can prepare a lot of tools and handicrafts, farmers and herdsmen can spare time to produce some handicrafts, improve Their own economic benefits; shrubs are excellent fuel, shrubs easy to stubble, easy to update, wet and dry can be burned, and the calorific value higher, can solve some of the peasant life energy; also a lot of shrubs or woody oil, rich Rich in nutrients, can improve the local people's food structure, improve their quality of life; legumes shrubs rich in nitrogen, the number of dead leaves and more, can be used as fertilizer to increase the soil phenanthrene, effectively improve Horqin Left Wing Middle Banner Barren desertification situation.

Many shrubs have very strong medicinal value on the roots, stems, flowers, leaves and fruits, and are very scarce for the society with frequent cancer, digestive diseases and cardiovascular diseases in the world. The large-scale planting of shrubbery in the flag can improve the local ecological environment, and can also make use of the medicinal value and production value of these shrubs to increase the income. 


\section{Influence of Shelterbelt Construction on Ecological and Economic Benefits of Horqin Left Wing Middle Banner}

\subsection{Reduce the rate of weathering}

Horqin Left Wing Middle Banner is located in the hinterland of Horqin Sandy Land where winds are larger and less rainfall occurs. There will be a large number of farmland and pastures being infested with sand and winds every spring. The construction of farmland shelterbelts can reduce the custom, lock the wind and sand, and the tree roots can retain water, and the deciduous trees are good fertilizers, turning the former sandy land into a fertile farmland.

\subsection{Increase air and soil moisture content}

In the effective protection distance of 20 times the tree height, the wind speed in shelterbelts is less than the bare sandy custom, and the water evaporation rate and evaporation in shelterbelt with 25 times the height of tree is $20 \%$ smaller than that in sandy shelterbelts. Shelterbelt has good Drought and moisturizing function. The wind speed in shelterbelt network becomes smaller and the moisture vaporized by soil and vegetation can stagnate for a longer period of time near the ground in the shelterbelt network. The air humidity in the shelterbelt network also increases, and the soil moisture content in the shelterbelt network also increases, Is very beneficial to seed germination and crop growth, especially in the dry season is very obvious. Horqin vigorously building shelterbelt can increase the local air humidity, reduce evaporation of surface water and vegetation moisture, lock the soil to retain more water, to create more favorable growth conditions for the growth of crops and other vegetation. Improve the ecological environment at the same time can also increase the yield of crops, improve economic returns.

\subsection{Adjust the temperature, prolong the growth period of crops and vegetation}

Horqin Left Wing Middle Banner accelerates warming in spring temperatures, windy and less rainfall, shelter can shield the erosion of sandstorms, the protection of ground heat will not easily be blown away, thereby increasing the temperature of early spring fields and pastures, as Seed germination grows to create good conditions. Shelterbelt air humidity is much higher than the sand, seed germination required practice will be 3 to 5 days earlier, the seed germination rate is also higher than the open area, but also extend the current frost-free period, reduce the impact of low humidity on crops ,Increase production.

\subsection{Can produce a large number of high-quality timber}

Farmland shelter forest is also a good wood production base. The farmland shelterbelt can improve the soil quality of Horqin Left Wing Middle Banner sandy land, the vegetation growth rate is also faster and the vegetation survival rate is higher, and the number of shelterbelt need to be updated and harvested so that the local farmers and herdsmen can sell timber, It is also possible to further process the timber itself, raise the value of the timber, and solve the surplus labor force in the area so as to increase the economic income.

\section{Conclusions}

The economic benefits of Horqin Left Wing Middle Banner mainly come from agriculture and animal husbandry. The industrial foundation is very weak. Farmers and herdsmen can not rely on agricultural science and technology and industrial facilities to raise their incomes. Farmers and herdsmen can only reclaim their land for cultivation in order to increase their income. Therefore, in order to improve the local economic benefits while controlling the problem of desertification in Horqin Left Wing Middle Banner, it is necessary to strengthen population control and supervise and manage land use, and guide the local people in building a reasonable At the same time, we must also increase education for local people, improve the cultural attainment of local people, increase industrial construction, and adjust the local industrial structure so as to increase local economic benefits through deep processing of agricultural and livestock products Horqin Left Wing Middle 
Banner economic resources carrying capacity. If we want to improve the local economic benefits on the basis of ensuring ecological balance, we also need the concerted efforts of the government, people from all walks of life and local people to constantly explore better construction plans.

\section{Acknowledgement}

This paper is a one of the research results of the general project of Scientific Research Project of Colleges and Universities in Inner Mongolia Autonomous Region, Research on Ecological and Economic Sustainable Development of Banner and County in China - Take Horqin Left Wing Middle Banner of Inner Mongolia for Example (NJSY13025).

\section{References}

[1] BaoYinDuRen, HaDaBaTer. Analysis of Mongolia Livestock Production and Livelihoods, World agriculture, 2014, 01.

[2] Zhou Jian, Zhang Fengrong, Xu Yan, et al..Land use / cover pattern and its changes in the ecotone between agriculture and animal husbandry in northern China under the chance precipitation and soil types: A case study from Horqin left wing, Geographical research, 2017, 07.

[3] Horqin Left Wing Middle Banner Annals Editorial Board.Horqin Left Wing Middle Banner Annals, Hailar:Inner Mongolia Culture Press, 2003.

[4] Ye Qing.Study on Utilization Efficiency of Agricultural Production Resources in Horqin Sandy Land, Huazhong Agricultural University, 2011, 06.

[5] Du Jiao.Study on County Economic Development of Horqin ZuoYi Zhong Flag,Central University for Nationalities, 2009, 03.

[6] China National Bureau of Statistics.China Statistical Yearbook, China Statistics Press, 1986-2017. 